\title{
Formation of Microphases and Constituents from Remaining Austenite Decomposition in API X80 Steel Under Different Processing Conditions
}

\author{
Rafael de Araujo Silva ${ }^{a *}$, Luís Felipe Guimarães de Souza ${ }^{b}$, \\ Eduardo Valencia Morales', Paulo Rangel Rios', Ivani de Souza Botte \\ ${ }^{a}$ Departamento de Engenharia de Materiais - DEMa, Universidade Federal de São Carlos - UFSCar, \\ Rod. Washington Luiz, Km 235, São Carlos, SP, Brazil \\ ${ }^{b}$ Departamento de Engenharia Mecânica, Centro Federal de Educação Tecnológica Celso Suckow da \\ Fonseca-CEFET, Av. Maracanã, 229, Bl E, 506, Maracanã, CEP 20271-110, Rio de Janeiro, RJ, Brazil \\ ${ }^{c}$ Departamento de Física, Universidad Central de Las Villas, 54830, Santa Clara, VC, Cuba \\ ${ }^{d}$ Universidade Federal Fluminense - EEIMVR, Av. dos Trabalhadores, 420, \\ CEP 27255-125, Volta Redonda, RJ, Brazil \\ ${ }^{e}$ Departamento de Engenharia Química e de Materiais - DEQM, \\ Pontifícia Universidade Católica do Rio de Janeiro-PUC-Rio, Rua Marques de S. Vicente, 225, \\ Gávea, CEP 222541-900, Rio de Janeiro, RJ, Brazil
}

Received: August 8, 2014; Revised: April 7, 2015

\begin{abstract}
The main goal this work is to evaluate the occurrence of the constituents and microphases observed in as-received API X80 pipe through the microstructures transformed from rich-carbon remaining austenite obtained via heat treatments. These heat treatments comprised austenitization at $1000^{\circ} \mathrm{C}$ for 30 minutes, followed by annealing at $700{ }^{\circ} \mathrm{C}, 623^{\circ} \mathrm{C}, 542{ }^{\circ} \mathrm{C}$ and $462{ }^{\circ} \mathrm{C}$ for 15,60 and 300 minutes and then cooling in water or still air. The effects of the increase in annealing parameters were: 1) the increase of microhardness values of the MA constituents and martensite islands, 2) the grain size of both ferritic phase and the martensite islands were increased, 3) the rise in the mean free path of ferrite and 4) the microstrains of samples were decreased. The cooling rates influenced significantly the transformation of carbon-rich remaining austenite to hard constituents and several microphases. After annealing at $700{ }^{\circ} \mathrm{C}$ during 60 min followed by quenching, the morphology of the MA constituents and its microhardness values were compatible for both heat-treated and as-received conditions.
\end{abstract}

Keywords: API $5 L$ X80, remaining austenite, carbon enrichment, martensite, granular bainite, MA constituent, aggregate of ferrite and carbides, scanning electron microscopy

\section{Introduction}

API steels are produced by thermomechanical controlled processing (TMCP) followed by interrupted accelerated cooling (IAC) above Ms or by TMCP without accelerated cooling using a careful alloy design and finishing rolling temperature in the dual phase field, where the main hardening mechanisms are grain refining and precipitation. Steels rolled in the dual phase field can present a complex and multiphasic microstructure. However, significantly transformations in microstructure occurs when the steel is submitted a thermal cycle with peak temperature of $1000{ }^{\circ} \mathrm{C}$, typical of several situations during service such as hot bending.

In the dual phase domain the steels present the formation of proeutectoid ferrite and part of austenite remains untransformed (remaining austenite). Depending on the carbon content and final cooling rate, the remaining austenite can be transformed into different phases and constituents.

This work studies the microstructural evolution of an API 5L X80 ( $\mathrm{Nb} \mathrm{Cr} \mathrm{Mo} \mathrm{V})$ steel obtained by heat treatments at laboratory scale without strain effects. This alloy was

austenitized and submitted to annealing followed by cooling in water or still air. Temperature and time were the variables in these heat treatments of annealing. The effect of the carbon content on the phase transformation of the remaining austenite was studied. The microstructural comparison was based on morphological aspects and in the correlation between the microhardness values of the MA constituents and martensite islands and its carbon contents.

\section{Literature Review}

In intercritical finishing rolling the coexistence of proeutectoid ferrite and remaining austenite results in an inhomogeneous microstructure ${ }^{1,2}$. The strain of austenite-ferrite mixture and the subsequent transformation of the remaining austenite and proeutectoid ferrite have received very little attention ${ }^{3}$. The strain in the dual phase field increases the total area of the austenite/ferrite interface that raises the rate of carbon and manganese diffusion during the ferrite growth ${ }^{4}$. The plastic strain of austenite influences the kinetics of ferrite formation ${ }^{5}$. In general, the austenite strain increases the $\mathrm{Ae}_{3}$

*e-mail: rafael.engmet@gmail.com 
temperature ${ }^{6}$. All this promotes the carbon enrichment of the remaining austenite during dual phase finishing rolling and significantly influences the final microstructure of as-received material.

The cooling rate affects the product from the remaining austenite transformation and its volumetric fraction ${ }^{7-11}$. However, the stability of austenite phase stems from significant differences in grain volume and carbon content from grain to grain ${ }^{12}$. This inhomogeneity of the carbon content in remaining austenite will form a complex microstructure after the final cooling stage ${ }^{13}$. In this process, the carbon atoms migrate to the austenite through the $\gamma / \alpha$ interface due to the lower carbon solubility in ferrite and then diffuse into the austenitic grain interior.

Since the ferrite transformation is extended, a large amount of austenite transforms to ferrite and the remaining austenite is more stable $\mathrm{e}^{10,14,15}$. The undercooling of austenite will influence in the carbon enrichment of remaining austenite because increasing the undercooling a lower volumetric fraction of proeutectoid ferrite will be formed and the time for the growth of ferrite will be small ${ }^{15}$. When the remaining austenite has eutectoid composition it is converted into pearlite ${ }^{16,17}$, however after water quenching the remaining austenite is transformed into as-quenched martensite $e^{6,18,19}$. The granular bainite is formed in the continuous cooling from the untransformed austenite under favorable conditions of chemical composition and appropriate cooling rates ${ }^{13}$. A granular bainite region is constituted by blocks of MA constituents dispersed in a ferritic matrix with any morphology. The MA constituents in granular bainite are carbon-enriched due to the partitioning of carbon to the remaining austenite during the austenitic decomposition ${ }^{20-22}$.

The addition of a large content of $\gamma$-stabilizer alloying elements, such as $\mathrm{C}, \mathrm{Ni}$, and $\mathrm{Mn}$, can stabilize the austenite below room temperature ${ }^{23}$. When the hardenability is increased by carbon enrichment of austenite is possible to use slow cooling rates to achieve a martensitic microstructure, avoiding the formation of ferrite, pearlite and bainite from remaining austenite decomposition ${ }^{22,24}$. However, some retained austenite may be present in microstructure after the final cooling ${ }^{25,26}$.

The martensite microhardness $(400-680 \mathrm{HV})^{[27,28]}$ can be correlated with the carbon content ${ }^{29}$. The carbon is the element that controls the martensite hardness ${ }^{22}$. The MA constituents have carbon content range from 0.5 to $0.8 \%{ }^{[30]}$. HSLA steels show carbon contents of the MA constituents from 0.6 up to $2.2 \%{ }^{[31,32]}$ independently of steel carbon content.

\section{Experimental Procedure}

The fluxogram of the developed work is presented in Figure 1. The API X80 steel of this work was produced by TMCP without accelerated cooling and sampled from a pipe obtained by the UOE process (U for U-ing cold forming from the plate, $\mathrm{O}$ for $\mathrm{O}$-ing cold forming from the $\mathrm{U}$ shape, E for cold expansion to meet the geometric tolerances). The steel rolling parameters were heating at $1250{ }^{\circ} \mathrm{C}$ for 300 minutes, roughing rolling between 1150 and $1000{ }^{\circ} \mathrm{C}$, finishing rolling in the dual phase field $\left(730^{\circ} \mathrm{C}\right)$ and after reaching $680{ }^{\circ} \mathrm{C}$, cooling in still air to room temperature. The chemical composition of steel is presented in Table 1.

The pipe sections were submitted to thermal cycles, as schematically shown in Figure 2. These heat treatments consist of austenitization at $1000{ }^{\circ} \mathrm{C}$ for $30 \mathrm{~min}$ followed

Table 1. API 5L X80 chemical composition.

\begin{tabular}{ccccccccc}
\hline \multicolumn{7}{c}{ Elements (wt. \%) } \\
\hline $\mathbf{C}$ & $\mathbf{M n}$ & $\mathbf{S i}$ & $\mathbf{P}$ & $\mathbf{S}$ & Al & Nb & V \\
\hline 0.05 & 1.74 & 0.21 & 0.018 & 0.002 & 0.042 & 0.069 & 0.022 \\
\hline \multicolumn{7}{c}{ Elements (wt.\%) } & & CE (wt. \%) \\
\hline $\mathbf{T i}$ & $\mathbf{N i}$ & $\mathbf{C r}$ & $\mathbf{C u}$ & $\mathbf{M o}$ & $\mathbf{N}$ & Pcm & IIW \\
\hline 0.014 & 0.011 & 0.147 & 0.008 & 0.177 & 0.005 & 0.17 & 0.41 \\
\hline
\end{tabular}

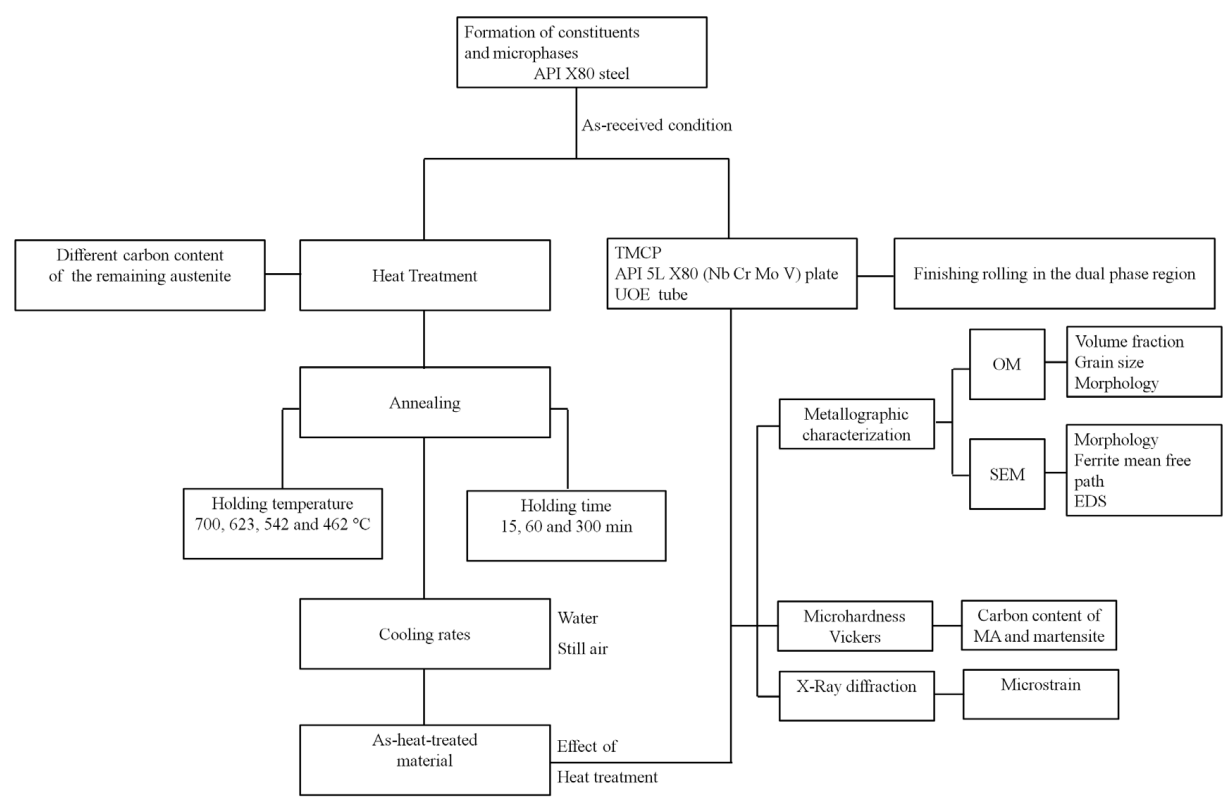

Figure 1. Work fluxogram. 
by a transfer to another furnace, where was applied the annealing. The samples were cooled in water or still air to room temperature during the final stage of thermal cycles. In general, the transformation temperatures were estimated from nominal chemical composition by empirical equations available in the literature ${ }^{33,34}$. The temperatures $\mathrm{Ar}_{3}=785^{\circ} \mathrm{C}$ and $\mathrm{Ar}_{1}=705^{\circ} \mathrm{C}$ were experimentally measured by dilatometry.

Transformation starting temperatures such as Bs $\left(623^{\circ} \mathrm{C}\right)$ and $\mathrm{Ms}\left(462{ }^{\circ} \mathrm{C}\right)$ were used as reference for the holding temperature in annealing, additionally an intermediary temperature $\mathrm{Bi}\left(542^{\circ} \mathrm{C}\right)$ between $\mathrm{Bs}$ and $\mathrm{Ms}$ and a temperature of $700{ }^{\circ} \mathrm{C}$ above $\mathrm{Bs}$, although below $\mathrm{Ar}_{3}\left(742{ }^{\circ} \mathrm{C}\right)$, were applied. These temperatures were calculated according to the empirical equations of Andrew's ${ }^{33}$ and Ouchi et al. ${ }^{34}$. Three different holding times were employed (15, 60 and 300 minutes) in order to promote different levels of carbon enrichment in the remaining austenite during annealing.

The metallographic characterization was performed on the cross section of the plate thickness, by optical microscopy (OM), scanning electron microscopy (SEM) and X-Ray diffraction (XRD). The microhardness Vickers measurements (HV 50g and HV $10 \mathrm{~g}$ ) of phases and constituents were obtained. The volumetric fractions of the carbon-rich constituents were determined by optical microscopy. The grain size and volumetric fractions were measured applying ASTM standard E-112 and ASTM standard E-562, respectively.

The determination of the martensite lattice parameter can give an indication of the carbon enrichment through X-Ray

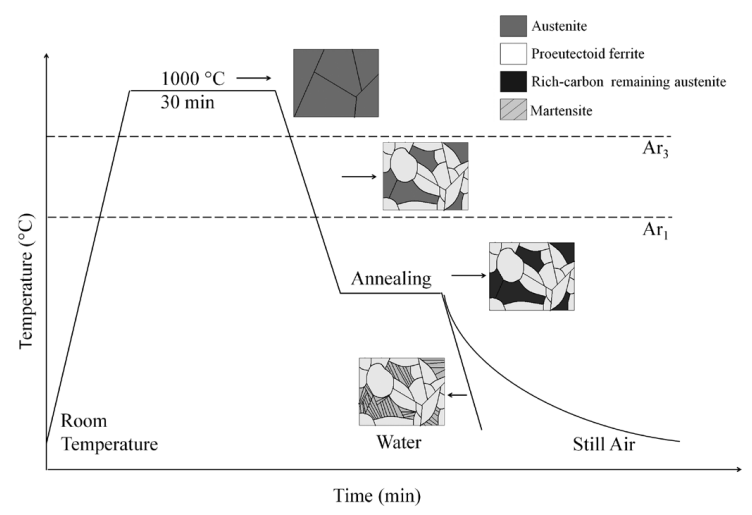

Figure 2. Schema of thermal cycles applied in this study. diffraction ${ }^{35,36}$, however in current work the carbon contents were estimated from the formula of $\operatorname{Hrivnak}^{31}$ (Equation 1).

$$
\% C_{M A}=\left(H V^{M A}-15\right) / 575
$$

The annealing parameters of holding time and temperature were varied to achieve different levels of carbon enrichment in the remaining austenite. After quenching, the microhardness values of martensite islands were measured and converted into the carbon contents by the formula of Hrivnak. These annealing parameters affect the effective carbon diffusion distance in the austenite from $\alpha / \delta$ interface ${ }^{37}$. This diffusion distance can be determined by Zener model, which shows that the increase in time raises the effective carbon diffusion distance in the austenite and the temperature have influence on the carbon diffusion coefficient in austenite ${ }^{37,38}$.

The X-Ray diffraction was realized in the Siemens D5000 $\mathrm{X}$-Ray diffractometer with $\mathrm{Cu} \mathrm{K}_{\alpha}$ radiation, step of $0.02^{\circ}$ $(2 \theta / 10 \mathrm{~s})$ and $2 \theta$ range from 20 to $140^{\circ}$. The microstrain $\left(\mathrm{e}_{0}\right)$ due the iron lattice distortion was obtained by the Rietveld analysis of the X-Ray diffraction data using the TOPAS Program.

The ferrite mean free path $\left(\mathrm{L}_{\alpha \alpha}\right)$ for the dislocation movement is the spacing between hard constituents in ferritic matrix. It was measured applying the methodology cited in literature ${ }^{39}$.

\section{Results}

The effects of heat treatments on API X80 steel were observed through the increase in annealing temperature and time. These increases promote: (1) the growth of the ferritic grain size and the martensite islands, (2) the increase of the microhardness values of the martensite islands (Table 2), (3) the rise of mean free path of ferrite and (4) the decrease of the microstrains (Table 3).

The empirical $\mathrm{Ar}_{3}$ temperatures of the remaining austenite regions were displaced to values below $\mathrm{Ar}_{1}$ temperature of steel due to carbon enrichment. This temperature $\left(\mathrm{Ar}_{1}\right)$ was measured by dilatometry $\left(705^{\circ} \mathrm{C}\right)$. The phase transformations from remaining austenite occurred in still air cooling or water cooling after annealing. These transformations did not occur during annealing within furnace because the remaining austenite was stabilized by high manganese and carbon contents.

The cooling rates influenced significantly the transformation of carbon-rich remaining austenite ${ }^{9}$. The microhardness

Table 2. Grain size, volumetric fraction and microhardness (HV) of ferrite and martensite.

\begin{tabular}{ccccccccc}
\hline & \multicolumn{2}{c}{ Annealing } & \multicolumn{3}{c}{ Ferrite } & \multicolumn{3}{c}{ Martensite } \\
\cline { 2 - 9 } Sample* & $\begin{array}{c}\text { Holding } \\
\text { Temperature }\left({ }^{\circ} \mathbf{C}\right)\end{array}$ & $\begin{array}{c}\text { Holding } \\
\text { Time }(\mathbf{m i n})\end{array}$ & $(\boldsymbol{\mu m})$ & $\mathbf{\%}$ & HV 50g & $(\boldsymbol{\mu m})$ & $\mathbf{\%}$ & HV 50g \\
\hline W4-15 & 462 & 15 & 6.26 & 79 & 182 & 10.8 & 21 & 322 \\
W6-15 & 623 & 15 & 8.18 & 72 & 155 & 24.9 & 28 & 327 \\
W7-15 & 700 & 15 & 10.6 & 65 & 157 & 30.9 & 35 & 369 \\
W7-60 & 700 & 60 & 12.5 & 85 & 167 & 31.0 & 15 & 488 \\
W7-300 & 700 & 300 & 13.4 & 81 & 182 & 25.2 & 19 & 501 \\
A7-300 & 700 & 300 & - & 87 & 159 & - & 13 & 407 \\
\hline
\end{tabular}

*Where $\mathrm{W}$ - Water cooling and A - Still Air cooling. These letters are followed by numerical characters to represent the holding temperature and holding time. 
values of ferrite, granular bainite and martensite (including MA constituents) cited in literature ${ }^{10,11}$ are in agreement with the observed values for the heat-treated samples after annealing time of $15 \mathrm{~min}$.

The resulting microstructures from the heat treatments corresponding to different thermal cycles are shown in Figures 3-6. The Figure 3 shows the as-received condition. In the Figure 4 can be observed the microstructures after the heat treatments. In the resulting microstructures can be observed that the as-received condition (rolled in the dual phase field) shows constituents and microphases of similar morphology when compared with the heat-treated conditions, such as martensite (Figures 3a, 4a, 4c, 4e, 4g and 4h), granular bainite (Figures 3b, 4b, 5d, 5h and 5i), MA constituents (Figures 3b, 4d and 5a), and aggregate of ferrite and carbides (Figures 3a, 4f, 5b, 5c, 5j, 5k, $5 \mathrm{l}$ and 6e). The aggregates of ferrite and carbides can be classified as degenerate pearlite or other microphases, such as lower bainite.

The Figure 5 shows the influence of temperature and cooling rates where the martensitic phase is present for all samples cooled in water, regardless the annealing temperature. Slower cooling rate promoted the formation of the aggregates of ferrite and carbides and MA constituents from remaining austenite.

The Figure 6 shows the influence of annealing time and cooling rates on the formation of constituents and microphases.
The influence of the cooling rates is more evident when the holding time is kept constant.

The microhardness distributions of ferrite, granular bainite, MA constituent and aggregate of ferrite and carbides can be observed in Figure 7. The influence of the hard constituents is shown by the bimodal microhardness distribution (Figure 8a) obtained after heat treatment with austenitization at $1000{ }^{\circ} \mathrm{C}$ followed by cooling to $700{ }^{\circ} \mathrm{C}$ for 15 minutes, and final cooling in water to room temperature. Therefore this bimodal distribution is due to the presence of ferrite (soft) and a hard second phase (such as martensite). The different classes of microhardness observed for the martensitic phase are due to the inhomogeneity of the carbon content within the grains $\mathrm{s}^{4,12,15}$. The Figure $8 \mathrm{~b}$ shows a microhardness profile (HV 10g) of one martensite island in the ferritic matrix.

\section{Discussion}

Thermal cycles with peak temperature of $1000{ }^{\circ} \mathrm{C}$ are typical of several situations during service such as welding and hot bending. In this study the microstructural evaluations after rapid thermal cycles of hot bending of the API X80 steel pipe have shown that the microphases and constituents are similar to those observed in the as-received condition due to the local conditions of carbon partitioning (Figure 9).

Table 3. Mean free path of ferrite $\left(\mathrm{L}_{\alpha \alpha}\right)$, microstrain $\left(\mathrm{e}_{0}\right)$ and martensite carbon content $(\mathrm{C})$ estimated from the formula of Hrivnak.

\begin{tabular}{cccccc}
\hline & \multicolumn{2}{c}{ Annealing } & & & \\
\cline { 2 - 3 } Sample* & $\begin{array}{c}\text { Holding } \\
\text { Temperature }\left({ }^{\circ} \mathbf{C}\right)\end{array}$ & $\begin{array}{c}\text { Holding } \\
\text { Time (min) }\end{array}$ & $\mathbf{L}_{\alpha u}(\boldsymbol{\mu m})$ & $\mathbf{e}_{\mathbf{0}}$ & C (wt. \%) \\
\hline W4-15 & 462 & 15 & 25.36 & 0.042 & 0.53 \\
W6-15 & 623 & 15 & 39.24 & 0.033 & 0.54 \\
W7-15 & 700 & 15 & 29.2 & 0.029 & 0.62 \\
W7-60 & 700 & 60 & 42.61 & 0.000 & 0.82 \\
W7-300 & 700 & 300 & 44.88 & 0.000 & 0.85 \\
A7-300 & 700 & 300 & 52.77 & 0.000 & 0.68 \\
\hline
\end{tabular}

*Where W-Water cooling and A - Still Air cooling. These letters are followed by numerical characters to represent the holding temperature and holding time.

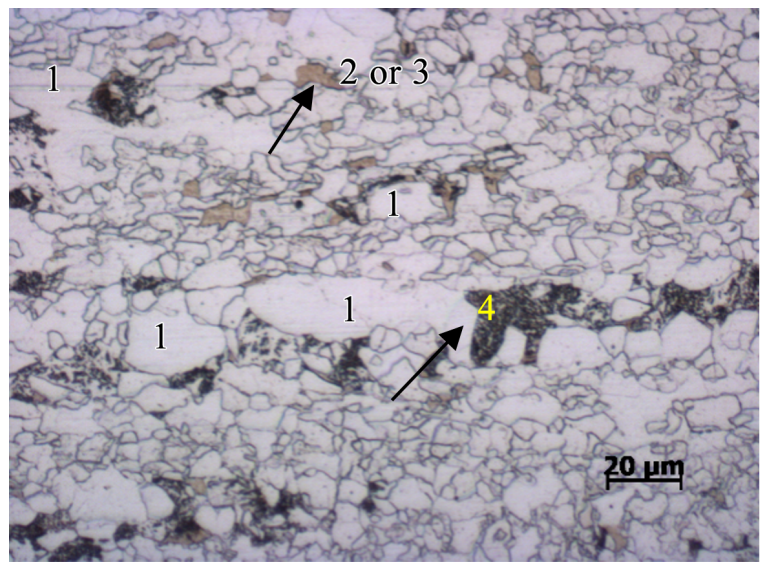

(a) Transverse cross-section

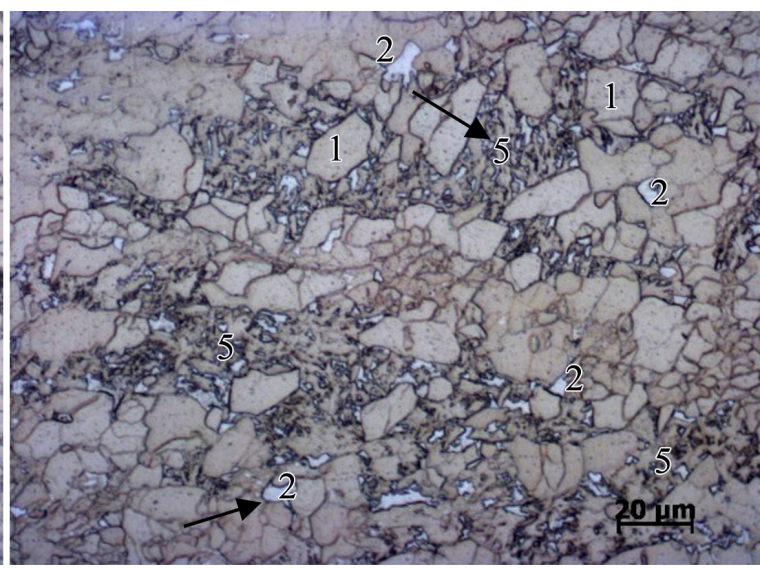

(b) Longitudinal section (rolling direction: horizontal)

Figure 3. Microphases and constituents of the as-received condition, (a) 2 pct Nital solution and (b) LePera modified method. 1 - proeutectoid ferrite, 2 - MA constituent (in white), 3 - martensite, 4 - aggregate of ferrite and carbides, 5 - granular bainite. 


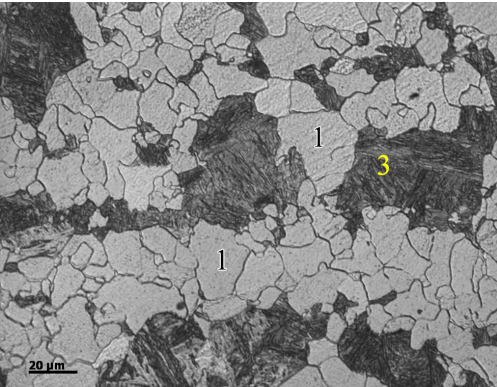

(a) W7-15

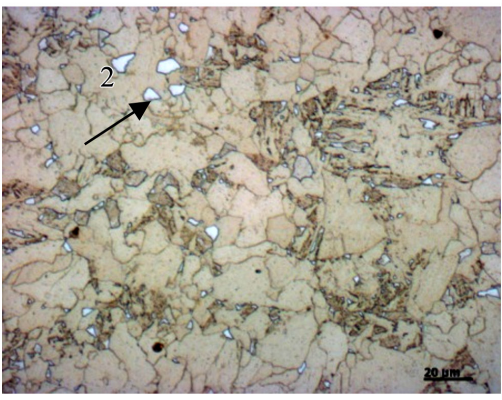

(d) W4-15

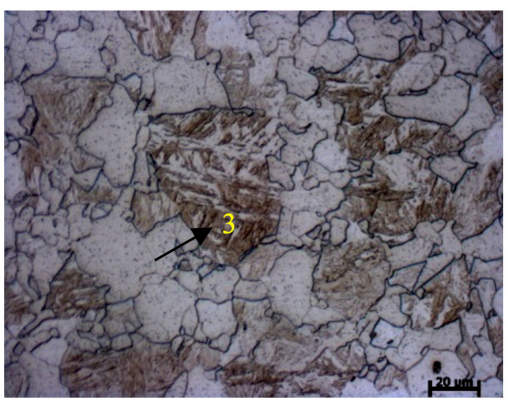

(g) W7-300

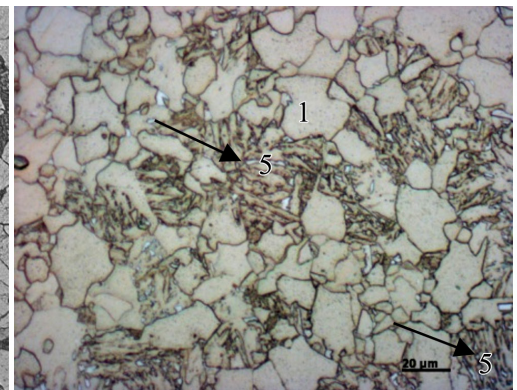

(b) A 7-15

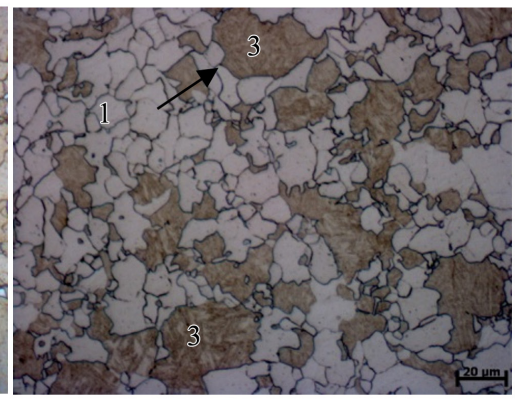

(e) W7-60

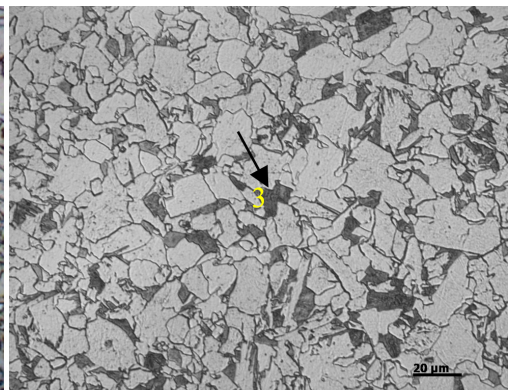

(c) W4-15

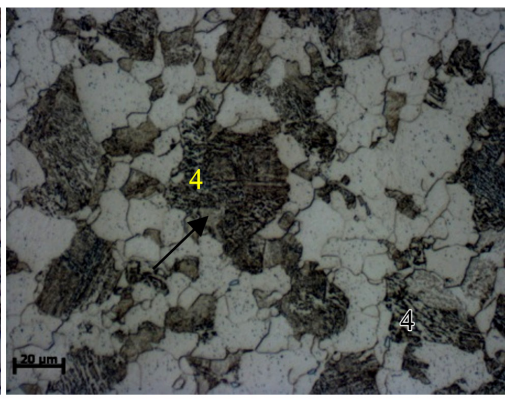

(f) $\mathrm{A} 7-60$

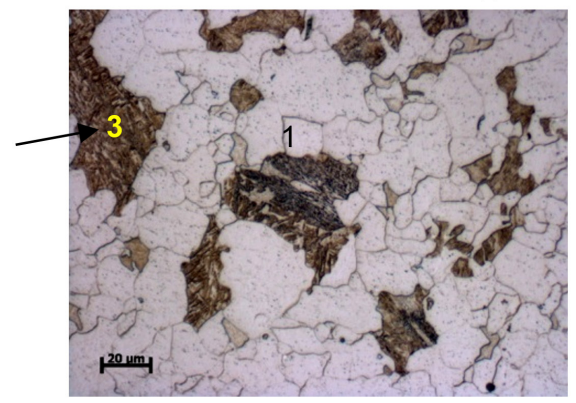

(h) $\mathrm{A} 7-300$

Figure 4. Influences of annealing parameters (time and temperature) on microstructure of API X80 steel. (a, c) 2 pct Nital solution, (b, d, $\mathrm{e}, \mathrm{f}, \mathrm{g}, \mathrm{h}$ ) LePera modified method. 1 - proeutectoid ferrite, 2 - MA constituent (in white), 3 - martensite, 4 - aggregate of ferrite and carbides, 5 - granular bainite. The codes of samples are explained in Tables 2 and 3 .

The MA constituents are possible because the pearlitic reaction is delayed during the continuous cooling due to high manganese content of studied steel.

In the heat-treated conditions, the carbon enrichment of remaining austenite is dependent of the annealing time and temperature ${ }^{4,14}$. High temperatures and high times of annealing increase the average effective carbon diffusion distance in the austenite from $\alpha / \gamma$ interface, and promote the carbon enrichment of remaining austenite. When the steel passes through the dual phase field during cooling, the carbon enrichment of remaining austenite occurs due to the formation of the proeutectoid ferrite because the carbon has low solubility in ferrite and high solubility in austenite. In this way, the remaining austenite was metastabilized below $\mathrm{Ar}_{1}$ temperature by the increase of carbon content and high manganese content of steel and this allowed an additional carbon enrichment of remaining austenite in different temperatures of annealing. The high carbon enrichment of the remaining austenite increased the microhardness levels of MA constituents and martensite due to the increase of hardenability ${ }^{4,12,40}$. For sample W7-300, EDS analyses did not reveal significant differences between the manganese and silicon contents of the martensite islands and the neighbouring ferrite grains. Thus, the hardenability of remaining austenite regions was directly associated with carbon contents.

The carbon enrichment of the metastable remaining austenite was favored by the high carbon diffusivity from proeutectoid ferrite to the remaining austenite due to the high annealing temperature of $700{ }^{\circ} \mathrm{C}$. Thus, the phase transformation from remaining austenite to hard constituents and microphases is influenced by the decrease of the annealing temperature. This decrease changes the undercooling below $\mathrm{Ae}_{3}$ and can influence the carbon solubility in ferrite and remaining austenite. The undercooling also influences the carbon diffusivity from proeutectoid ferrite to remaining austenite.

The decrease of microstrain (obtained via the XRD) can be correlated with the increase in ferritic mean free path and with the decrease of carbon content in ferrite due to the diffusion to the remaining austenite, however, the precipitation in ferrite during the annealing can induce microstrains. 


\section{As-received}

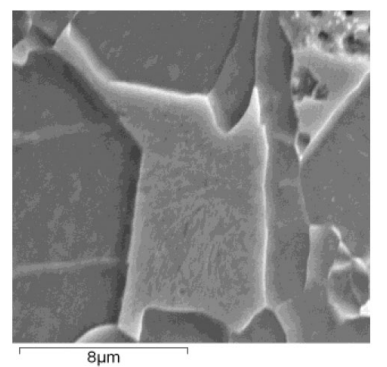

(a)

$516 \pm 89 \mathrm{HV}$

$(0.72-1.02 \% \mathrm{C})$

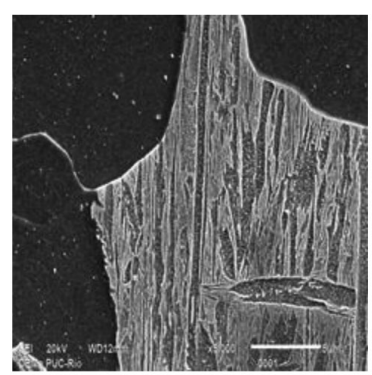

(e) W7-15

$369 \pm 28 \mathrm{HV}$

$(0.57-0.66 \%)$

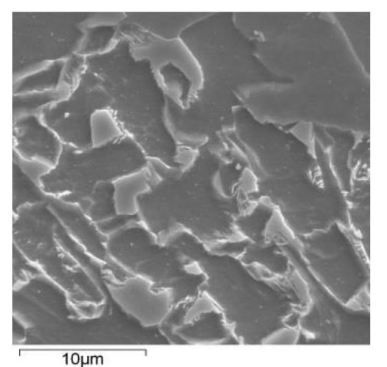

(i) A7-15

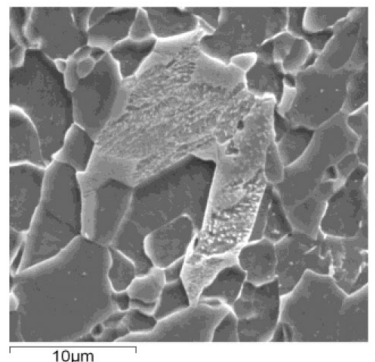

(b)

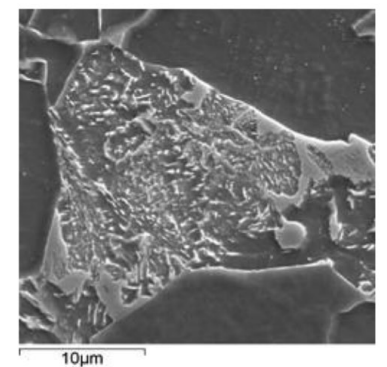

(c)

$334 \pm 32 \mathrm{HV}$

$334 \pm 32 \mathrm{HV}$

Water cooled

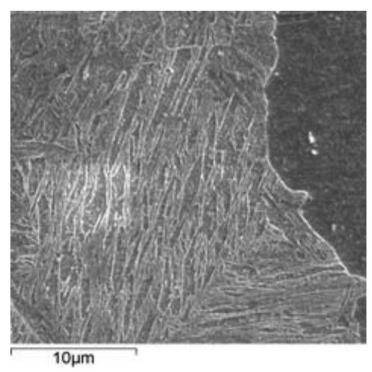

(f) W6-15

$327 \pm 43 \mathrm{HV}$

$(0.47-0.62 \% \mathrm{C})$

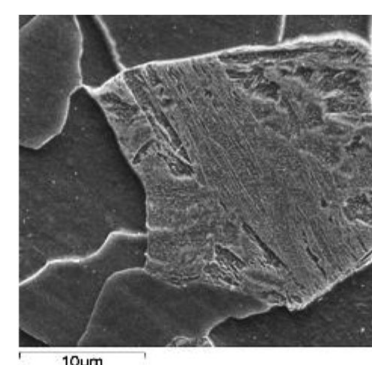

(g) W5-15

$346 \pm 20 \mathrm{HV}$

$(0.54-0.61 \% \mathrm{C})$

Air Cooled

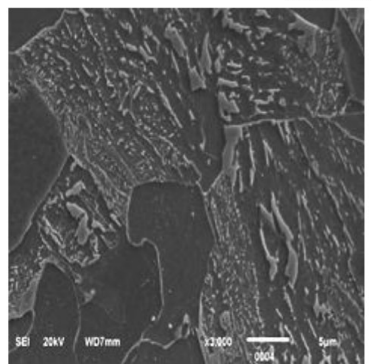

(j) A6-15

$230 \pm 17 \mathrm{HV}$

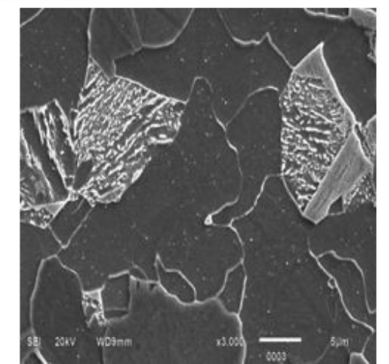

(k) A5-15 $257 \pm 20 \mathrm{HV}$

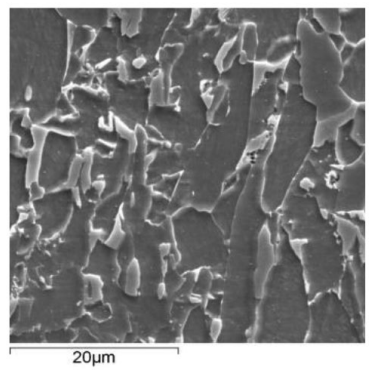

(d)

\section{$211 \pm 9 \mathrm{HV}$}

Figure 5. Microstructural details in proeutectoid ferrite matrix observed by Scanning Electron Microscopy of the as-received and heat-treated conditions and microhardness, HV 10g and HV 50g (carbon range). The codes of samples are explained in Tables 2 and 3. The microhardness values were measured inside the second phases and constituents.

The final cooling in water at room temperature restrained and reduced the precipitation process inside the martensite islands. The quenching was favorable to the formation of martensite from carbon-rich remaining austenite after the annealing heat treatment and it made possible the calculation of carbon content of the martensite possible. However, a low silicon content rises the austenite precipitation rate ${ }^{41}$ and decreases the carbon enrichment of austenite. Other factor is the decrease of the carbon contents of martensite solid solution due to precipitation, which underestimates the martensite carbon content obtained through the correlation with the microhardness (formula of Hrivnak).
It is well known that the local carbon enrichment can play an important role in the transformation temperature ${ }^{4,10-22,26}$, for example, the reduction of the carbon content in the remaining austenite increases Ms temperature. Also, the high cooling rates displace the $\mathrm{Ar}_{3}$ temperature of steel, decreasing its value and favoring the partial or total transformation of bainite and martensite. The metastability of the remaining austenite is directly associated with its carbon content and the products of austenite decomposition will depend of final cooling rates. In general, the higher the carbon content and the cooling rate, the higher the hardness of secondary phases formed ${ }^{4,12,40}$. When the carbon enrichment of austenite reaches high contents, the martensite can be obtained by applying 


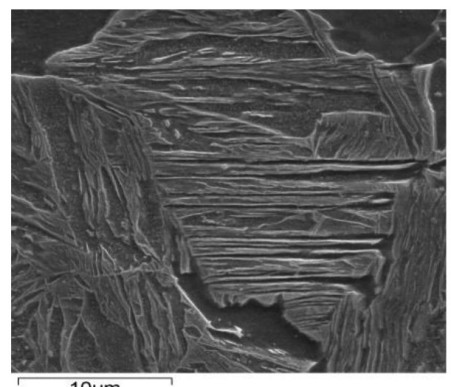

$10 \mu \mathrm{m}$

(a) W7-15

$369 \pm 28 \mathrm{HV}$

$(0.57-0.66 \% \mathrm{C})$

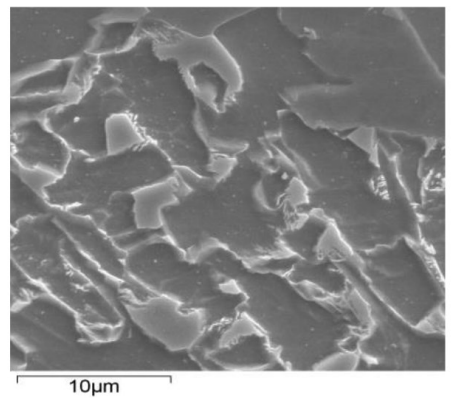

(d) A7-15

$211 \pm 9 \mathrm{HV}$

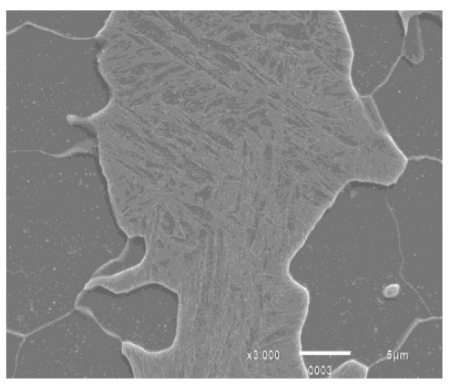

(b) W7-60

$488 \pm 111 \mathrm{HV}$

$(0.63-1,01 \% \mathrm{C})$

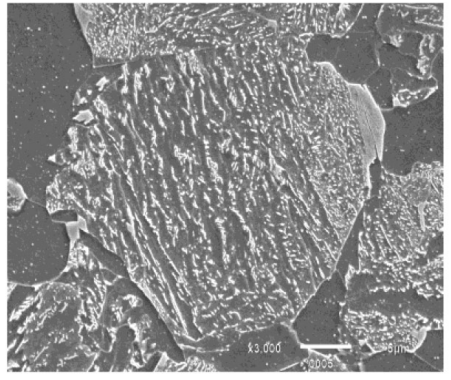

(e) A7-60

$258 \pm 36 \mathrm{HV}$

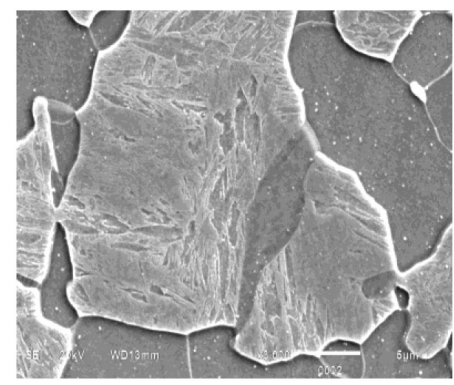

(c) W7-300

$501 \pm 77 \mathrm{HV}$

$(0.71-0.98 \% \mathrm{C})$

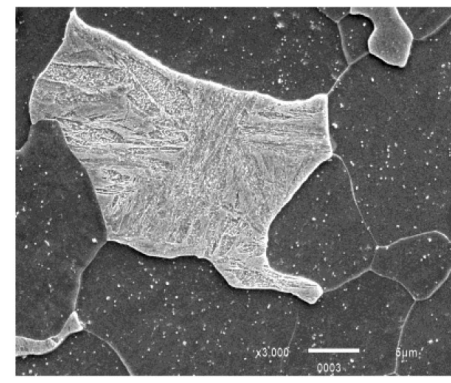

(f) A7-300

$407 \pm 65 \mathrm{HV}$

$(0.57-0.79 \% \mathrm{C})$

Figure 6. Microstructural evolution in proeutectoid ferrite matrix and microhardness HV 50g (carbon range) according to time and cooling rate for annealing at $700{ }^{\circ} \mathrm{C}$, observed by SEM. The codes of samples are explained in Tables 2 and 3. The microhardness values were measured inside the second phases and constituents.

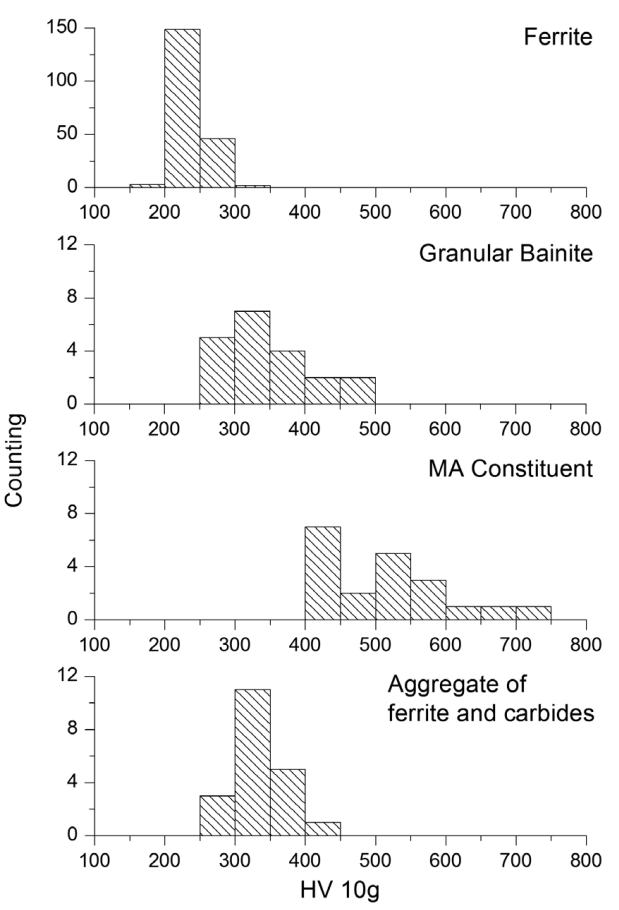

Figure 7. Microhardness distribution of the as-received material for ferritic matrix, granular bainite, aggregates of ferrite and carbides and MA constituent. of low cooling rates ${ }^{24}$. This was observed for the sample A7-300 (Table 3 and Figures $4 \mathrm{~h}$ and 6f).

It was observed that the differences between the austenitizing and annealing temperatures can play an important role on the final microstructure being particularly important to the microhardness of the proeutectoid ferrite, which increased with the rise of the difference between the austenitizing and annealing temperatures. The association of high temperatures and high holding times with low cooling rates led to a coarse precipitation, while faster cooling rates produced second phase hardening. Beladi et al ${ }^{42}$ suggests that the rate of ferrite nucleation in the remaining austenite decreased with holding time, and the remaining austenite becomes enriched in carbon and starts the transformation to pearlite at a holding time of $90 \mathrm{~min}$. In this work, the lamellar pearlite was not observed after annealing time of $300 \mathrm{~min}$ and final cooling in air, because the high manganese content of steel delays the pearlitic reaction. By increasing the annealing time or the ferrite volumetric fraction at a given temperature, the remaining austenite becomes more homogeneous and enriched in carbon.

The Figure 5 shows the Vickers microhardness $(516 \pm 89)$ obtained for the MA constituents in the as-received condition. Similar microhardness values were observed for the islands of martensite after heat treatments (W7-60 and W7-300). Thus, the local carbon contents could be compatible. The different carbon contents can explain the several morphologies of 
martensite transformed from the remaining austenite after quenching due to the displacement of Ms temperature. The martensite can be observed in different morphologies, such as fine plates, laths and lenticular laths ${ }^{43}$. The lower

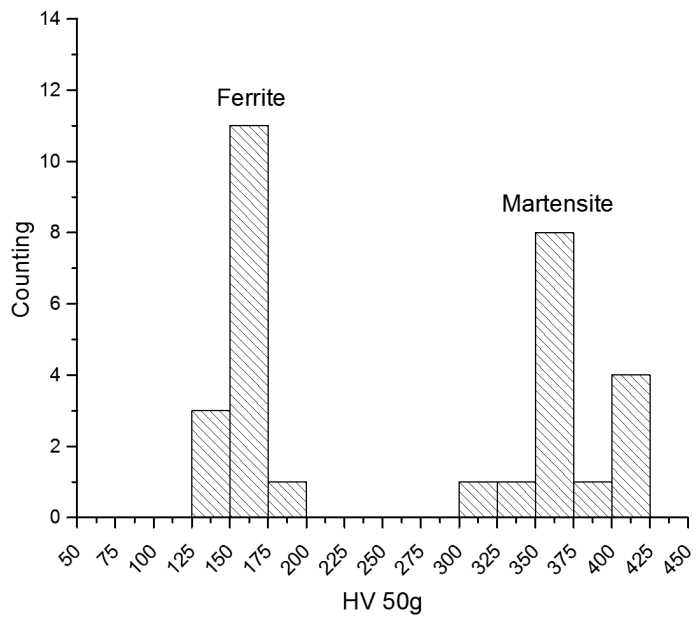

(a) bainite can be transformed from the remaining austenite with carbon content higher than $0.32 \% \mathrm{C}^{43}$ and cooled to a temperature below the bainitic transformation start (Bs temperature), under suitable cooling rates. However, a

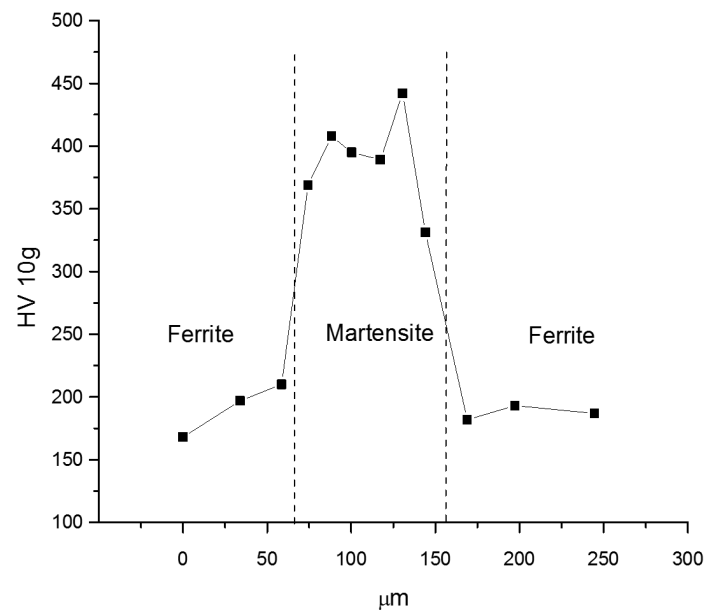

(b)

Figure 8. Microhardness distribution after heat treatment (a) of ferrite grains and martensite (b) microhardness profile for one martensite island of sample W7-15.

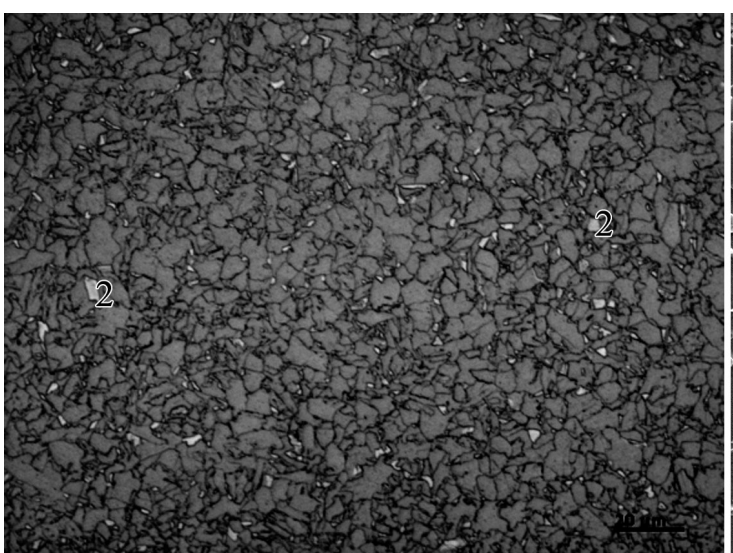

(a)

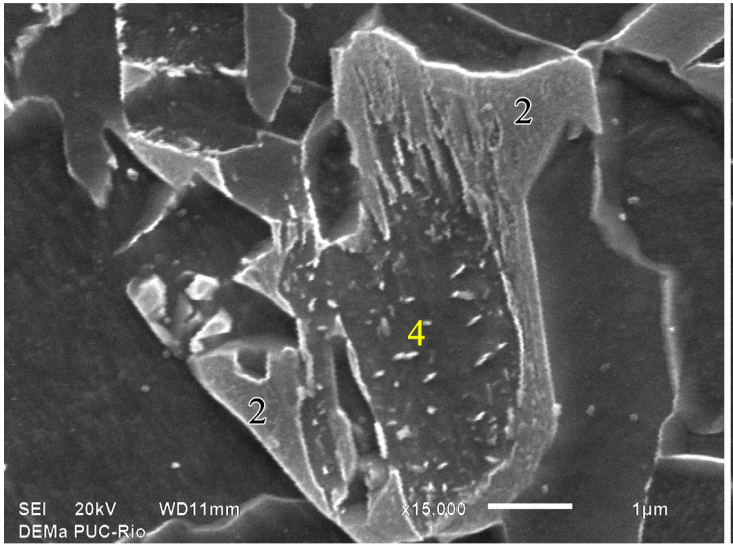

(c)

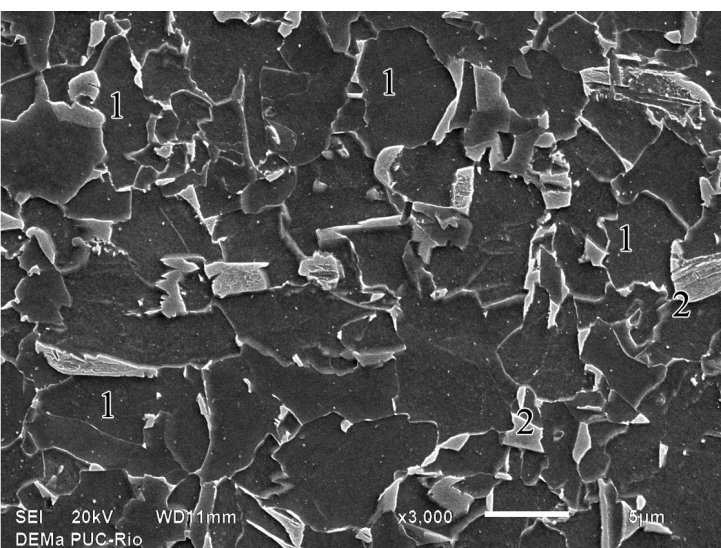

(b)

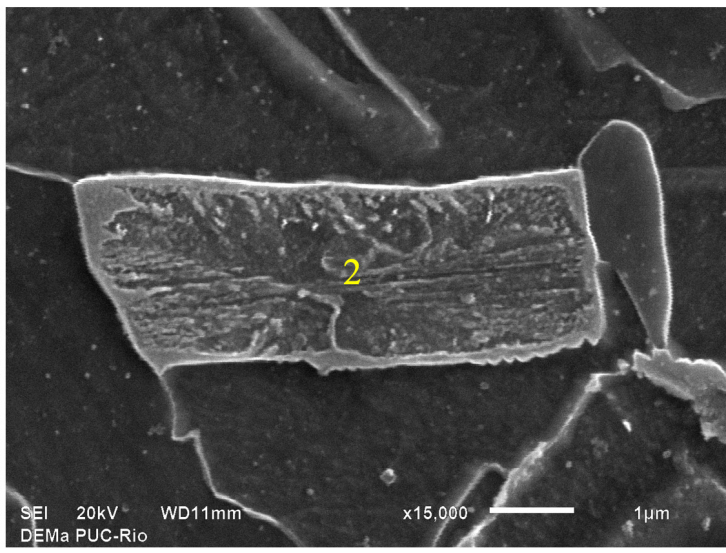

(d)

Figure 9. Microphases and constituents from API X80 pipe after hot bending. Mid-thickness of Extrados. Extrados is the outer curve of a bent pipe, where the wall thinning occurs. (a) LePera modified, OM (b, c and d) 2 pct Nital, SEM. 1 - proeutectoid ferrite, 2 - MA constituent and 4 - aggregate of ferrite and carbides. 
mixed microstructure can be obtained due to heterogeneity of the local carbon enrichment of the remaining austenite before the final cooling stage.

For the as-received condition, it was observed that the final degree of total strain of the rolling schedule and the strain in finishing rolling can have a strong influence in carbon enrichment of the remaining austenite due to the evolution of ferritic reaction ${ }^{1-6}$. The volumetric fraction of the hard constituents in final microstructure increases with the intercritical finishing rolling ${ }^{44}$. In this work a mixed microstructure (ferrite, aggregates of ferrite and carbides, MA constituents, martensite, granular bainite) were observed in the as-received condition after TMCP with final cooling in the still air. These complex microstructures can result from the heterogeneity of the carbon enrichment of the remaining austenite formed in thermomechanical process, with finishing rolling in dual phase field.

\section{Summary and Conclusions}

This characterization methodology allowed to identify with confidence the microstructure observed in the as-received condition. The heterogeneity of the carbon enrichment of the remaining austenite in the dual phase field yields a complex multiphasic microstructure.

The increase in annealing parameters caused the rise of the ferrite volumetric fraction. The carbon content of remaining austenite and microhardness values of martensite islands were increased too. When annealing time and temperature are raised, the sizes of both ferrite grains and martensite

\section{References}

1. Huang YD and Froyen L. Important factors to obtain homogeneous and ultrafine ferrite-pearlite microstructure in low carbon steel. Journal of Materials Processing Technology. 2002; 124(12):216-226. http://dx.doi.org/10.1016/S0924-0136(02)00163-2.

2. Eghbali $B$ and Abdollah-zadeh A. Influence of deformation temperature on the ferrite grain refinement in a low carbon $\mathrm{Nb}-\mathrm{Ti}$ microalloyed steel. Journal of Materials Processing Technology. 2006; 180(1-3):44-48. http://dx.doi.org/10.1016/j. jmatprotec.2006.04.018.

3. Eghbali B. Study on the ferrite grain refinement during intercritical deformation of a microalloyed steel. Materials Science and Engineering A. 2010; 527(15):3407-3410. http:// dx.doi.org/10.1016/j.msea.2010.01.075.

4. Garcia-Gonzalez JE. Fundamental study of the austenite formation and decomposition in Low-Si, Al added TRIP steels. [Thesis]. Pittsburgh: University of Pittsburgh; 2005.

5. Eghbali B and Abdollah-Zadeh A. Deformation-induced ferrite transformation in a low carbon $\mathrm{Nb}-\mathrm{Ti}$ microalloyed steel. Materials \& Design. 2007; 28(3):1021-1026. http://dx.doi. org/10.1016/j.matdes.2005.11.006.

6. Eghbali B and Abdollah-Zadeh A. The influence of thermomechanical parameters in ferrite grain refinement in a low carbon Nb-microalloyed steel. Scripta Materialia. 2005; 53(1):41-45. http://dx.doi.org/10.1016/j.scriptamat.2005.03.014.

7. Wilson AD, Hamburg EG, Colvin DJ, Thompson SW and Krauss G. Properties and microstructures of copper precipitation aged plate steels. In: Proceedings International Conference on Microalloyed HSLA Steel, Microalloying '88; 1988; Ohio, USA. Ohio: ASM International; 1988. p. 259-275. islands increase and the same occurs with the mean free path of ferrite, while the microstrains are decreased.

Different morphologies of martensite were observed after quenching due to the displacement of Ms temperature in function of different carbon contents of the remaining austenite. The martensitic microstructure could be obtained from remaining austenite after air cooling due to the local carbon contents higher than 0.71 wt. \% associated with the high manganese content of the nominal chemical composition.

After the annealing stage significant effects due to applications of different cooling rates were discovered in morphologies of microstructure transformed from remaining austenite. The martensite volumetric fraction was favored by the steel intercritical processing associated with water cooling to room temperature. The formations of massive MA constituents and the granular bainite were favored by still air cooling rate.

The morphologies and the microhardness values of constituents and microphases in as-heat-treated conditions were compatible with the microstructure of as-received condition. After annealing at $700{ }^{\circ} \mathrm{C}$ for $60 \mathrm{~min}$ followed by quenching, the morphology of the martensite islands, its microhardness values and its carbon contents were compatible with those of the MA constituents observed on the as-received condition.

\section{Acknowledgements}

The authors are grateful to CNPq, CAPES and FAPERJ for financial support.

8. Dhua SK, Mukerjee D and Sarma DS. Effect of cooling rate on the as-quenched microstructure and mechanical properties of HSLA-100 steel plates. Metallurgical and Materials Transactions. A, Physical Metallurgy and Materials Science. 2003; 34(11):2493-2504. http://dx.doi.org/10.1007/s11661003-0009-0.

9. Beladi H, Kelly GL, Shokouhi A and Hodgson PD. Effect of thermomechanical parameters on the critical strain for ultrafine ferrite formation through hot torsion testing. Materials Science and Engineering A. 2004; 367(1-2):152-161. http://dx.doi. org/10.1016/j.msea.2003.09.095.

10. Zhang YQ, Zhang HQ, Liu WM and Hou H. Effects of $\mathrm{Nb}$ on microstructure and continuous cooling transformation of coarse grain heat-affected zone in $610 \mathrm{MPa}$ class high-strength low-alloy structural steels. Materials Science and Engineering A. 2009; 499(1-2):182-186. http://dx.doi.org/10.1016/j.msea.2007.10.118.

11. Jun HJ, Kang JS, Seo DH, Kang KB and Park CG. Effects of deformation and boron on microstructure and continuous cooling transformation in low carbon HSLA steels. Materials Science and Engineering A. 2006; 422(1-2):157-162. http:// dx.doi.org/10.1016/j.msea.2005.05.008.

12. Jimenez-Melero E, van Dijk NH, Zhao L, Sietsma J, Offerman SE, Wright JP, et al. The effect of aluminium and phosphorus on the stability of individual austenite grains in TRIP steels. Acta Materialia. 2009; 57(2):533-543. http://dx.doi.org/10.1016/j. actamat.2008.09.040.

13. Thewlis G. Classification and quantification of microstructures in steels. Materials Science and Technology. 2004; 20(2):150. http://dx.doi.org/10.1179/026708304225010325.

14. Borgenstam A, Hillert M and Ågren J. Metallographic evidence of carbon diffusion in the growth of bainite. Acta 
Materialia. 2009; 57(11):3242-3252. http://dx.doi.org/10.1016/j. actamat.2009.03.026.

15. Offerman SE, van Wilderen LJGW, van Dijk NH, Sietsma J, Rekveldt MT and van der Zwaag S. In-situ study of pearlite nucleation and growth during isothermal austenite decomposition in nearly eutectoid steel. Acta Materialia. 2003; 51(13):39273938. http://dx.doi.org/10.1016/S1359-6454(03)00217-9.

16. Callister WD. Materials science and engineering: an introduction. 7th ed. Nova Jersey: John Wiley \& Sons; 2007. 975 p.

17. Garrison WM Jr. Steels: classifications. In: Buschow KHJ, Cahn RW, Flemings MC, Ilschner B, Kramer EJ, Mahajan S and Veyssière P, editors. Encyclopedia of materials: science and technology. 2nd ed. Oxford: Elsevier; 2001. p. 8840-8843.

18. George VV. Etching isothermally treated steels. Heat Treating Progress. 2001; 1(2):25-32.

19. Sajjadi SA and Zebarjad SM. Isothermal transformation of austenite to bainite in high carbon steels. Journal of Materials Processing Technology. 2007; 189(1-3):107-113. http://dx.doi. org/10.1016/j.jmatprotec.2007.01.011.

20. Tang $Z$ and Stumpf W. The role of molybdenum additions and prior deformation on acicular ferrite formation in microalloyed $\mathrm{Nb}-\mathrm{Ti}$ low-carbon line-pipe steels. Materials Characterization. 2008; 59(6):717-728. http://dx.doi.org/10.1016/j.matchar.2007.06.001.

21. Yang J-H, Liu Q-U, Sun D-B and Li X-Y. Microstructure and transformation characteristics of acicular ferrite in high niobiumbearing microalloyed steel. Journal of Iron and Steel Research International. 2010; 17(6):53-59. http://dx.doi.org/10.1016/ S1006-706X(10)60114-8.

22. Llewellyn DT and Hudd RC. Steels: metallurgy and applications. 3rd ed. Oxford: Butterworth-Heinemann; 1998. p. 199-290.

23. Paulo RR and Angelo FP. Precipitation from Austenite. In: Buschow KHJ, Cahn RW, Flemings MC, Ilschner B, Kramer EJ, Mahajan S, and Veyssière P, editors. Encyclopedia of materials: science and technology. 2nd ed. Oxford: Elsevier; 2005. p. 1-7.

24. Nürnberger F, Grydin O, Yu Z and Schaper M. Microstructural behaviour of tempering steels during precision forging and quenching from hot-forming temperatures. Metallurgical and Mining Industry. 2011; 3(7):79-86.

25. Zhao J-C and Notis MR. Continuous cooling transformation kinetics versus isothermal transformation kinetics of steels: a phenomenological rationalization of experimental observations. Materials Science and Engineering. 1995; 15(4-5):135-207. http://dx.doi.org/10.1016/0927-796X(95)00183-2.

26. Kammouni A, Saikaly W, Dumont M, Marteau C, Bano X and Charaï A. Effect of the bainitic transformation temperature on retained austenite fraction and stability in Ti microalloyed TRIP steels. Materials Science and Engineering. 2009; 518(1-2):8996. http://dx.doi.org/10.1016/j.msea.2009.05.015.

27. Gorni AA and Vieira RR. The effect of finishing temperature and cooling rate on the microstructure and mechanical properties of an as-hot-rolled dual phase steel. In: International Congress HSLA '90; 1990; Beijing, China. Beijing: The Chinese Society of Metal; 1990. p. 1-22.

28. Shen HP and Lei TC. Shear lag analysis of strength of dual phase steels. Metal Science. 1984; 18(5):257-264. http://dx.doi. org/10.1179/030634584790420078.
29. Honeycombe RWK. Steels: microstructure and properties. 1st ed. London: Edward Arnold; 1981. p. 70-153.

30. Hiroshi I, Hiroaki $\mathrm{O}$ and Toyoaki T. Effect of martensiteaustenite constituent on HAZ toughness of a high strength steel. Transactions of Japan Welding Society. 1980; 11(2):3-12.

31. Hrivnak I, Matsuda F, Li Z, Ikeuchi K and Okada H. Investigation of metallography and behaviour of M-A constituent in weld HAZ of HSLA steels. Transactions of Japan Welding Institute. 1992; 21(2):101-110.

32. Choi SD, Kim HS, Je JH and Park SH. Annealing behavior of retained austenite in low carbon steel: real time synchrotron X-ray scattering study. Journal of Materials Science Letters. 2002; 21(5):353-355. http://dx.doi.org/10.1023/A:1014990714332.

33. Andrews KW. Empirical formulae for the calculation of some transformation temperatures. Journal of the Iron and Steel Institute. 1965; 203:721-727.

34. Ouchi C, Sampei T and Kozasu I. The effect of hot rolling condition and chemical composition on the onset temperature of gamma-alpha transformation after hot rolling. Transactions of the ISIJ. 1982; 22: 214-222.

35. Cullity BD. Elements of X-ray diffration. 2nd ed. Reading: Addison-Wesley Publishing Company; 1978. p. 347-361.

36. Reed-Hill t RE. Physical metallurgy principles. 2nd ed. Princeton: Van Nostrand; 1964. 721 p.

37. Montes CC. Modeling of diffusional phase transformation during the isothermal decomposition of austenite in a carbon manganese (0,37C-1,5Mn) microalloyed with vanadium and titanium. [Thesis]. Madrid: Universidad Complutense de Madrid; 1999.

38. American Society for Metals - ASM. ASM handbook: alloy phase diagrams. Ohio: ASM International; 1992. v. 3. p. 2110.

39. Uggowitzer P and Stuewe HP. Plasticity of ferritic-martensitic two-phase steels. Zeitschrift fur Metallkunde. 1982; 73(5):277285.

40. Hicho GE and Fields RJ. Effects of varying austenitizing temperature and cooling rate on the ability of HSLA- 80 steel to achieve a yield strength comparable to HSLA-100. Journal of Heat Treating. 1988; 6(2):77-85. http://dx.doi.org/10.1007/ BF02833108.

41. Davies RG. The deformation behavior of a vanadium-strengthened dual phase steel. Metallurgical Transactions. A, Physical Metallurgy and Materials Science. 1978; 9(1):41-52. http:// dx.doi.org/10.1007/BF02647169.

42. Beladi H, Timokhina IB, Mukherjee S and Hodgson PD. Ultrafine ferrite formation through isothermal static phase transformation. Acta Materialia. 2011; 59(10):4186-4196. http://dx.doi.org/10.1016/j.actamat.2011.03.043.

43. Bhadeshia HKDH. Bainite in steels. 2nd ed. London: IOM Communications; 2001. $460 \mathrm{p}$.

44. Byoungchul H, Chang GL and Sung-Joon K. Low-temperature toughening mechanism in thermo-mechanically processed high-strength low-alloy steels. Metallurgical and Materials Transactions. A, Physical Metallurgy and Materials Science. 2010; 42A:717-728. 